\title{
Politics of a Transformative Rural: Development, Dispossession and Changing Caste-Relations in West Bengal, India
}

\section{Ritanjan Das}

\section{(2) OpenEdition}

\section{Journals}

Electronic version

URL: http://journals.openedition.org/samaj/5472

DOI: $10.4000 /$ samaj.5472

ISSN: 1960-6060

\section{Publisher}

Association pour la recherche sur l'Asie du Sud (ARAS)

\section{Electronic reference}

Ritanjan Das, «Politics of a Transformative Rural: Development, Dispossession and Changing CasteRelations in West Bengal, India », South Asia Multidisciplinary Academic Journal [Online], 21 | 2019 , Online since 29 July 2019, connection on 17 September 2019. URL : http://journals.openedition.org/ samaj/5472 ; DOl : 10.4000/samaj.5472

This text was automatically generated on 17 September 2019

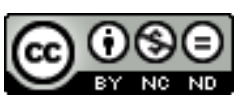

This work is licensed under a Creative Commons Attribution-NonCommercial-NoDerivatives 4.0 International License. 


\title{
Politics of a Transformative Rural: Development, Dispossession and Changing Caste-Relations in West Bengal, India
}

\author{
Ritanjan Das
}

1 Displacement from land and the concomitant dispossession of economic and social capital is arguably one of the biggest domains of struggle in contemporary rural and peri-urban India. It is, however, hardly a new phenomenon, as from the widely prevalent and rarely accountable land encroachment practices during colonial times through to the Nehruvian project of nation building post-independence, narratives of land acquisition and associated displacements remain all too familiar to date. There is ongoing dispossession of farmers induced by state-sponsored property speculation and business interests in many forms: SEZs (Levien 2012, 2013; Cross 2014), large scale mining projects (Padel and Das 2010), conservation (Münster and Münster 2012), agribusiness, housing, and industrialization (Nielsen 2018; Nielsen and Oskarsson 2017; Akram-Lodhi 2009). In fact, close to 100 million people are likely to have been displaced since independence (Cernea 2016).

2 The theme of struggles around land and the associated rural transformation are of course major characteristics of contemporary development politics in India, where the transition to capitalism is more entrenched today than ever before (Harriss-White and Heyer 2015:4). Continually newer, more efficient modes of resource capitalism-or, the "extraction of value from nature" at minimal costs (Woods 2011:53)-are accompanying high economic growth. The accumulation of capital through dispossession of rural lands, forests, and other raw materials (Levien 2012; Goldman 2011; Gooptu 2011, etc.) appears to have favored corporate businesses, industrial or real estate, with "city making" emerging as a key avenue for profitable investments (Levien 2012; Harriss-White and Heyer 2015:10-11). Social differentiation and precarity have also intensified correspondingly. Dispossessions have contributed to the rise of vulnerable, 
disenfranchised, casual labor on a significant scale. Swelled ranks of "footloose labour" employed in low-wages causal jobs are unmistakable across rural and urban areas today (Breman 2007; Guerin, Venkatsubramian, and Michiels 2015). Among the far reaching upshots of these transforming forces, one of the most notable has been the reconstruction of the "urban" as a crucial and strategic site for the unfolding of global and national scale projects, which in turn has not only led to a concomitant reduction of the perceived value of the rural (Roy 2002, 2005; Sassen 2006), but as this paper goes on to demonstrate, also a fundamental shift in rural socioeconomic relations.

The story that unfurls in this paper recounts the transformation of Rajarhat-an erstwhile rural settlement in the state of West Bengal, adjacent to state capital Kolkata-into an upmarket satellite township, comprised mostly of business/IT hubs, luxury real estate, and shopping malls. Although seen as a symbol of Kolkata's resurgence, Rajarhat is simultaneously a story of "continuous cycle[s] of evictions, expropriations, ecological degradation, and social protest" (Bose 2013:127). Furthermore, political struggles around displacement aside, Rajarhat also provides an intriguing window into the subtle, multifaceted transformation of socio-economic relations within the remnants of erstwhile rural spaces, viewed through a lens of changing caste-relations and newer forms of economic engagement. While land struggles in West Bengal have been under extensive scrutiny in recent times, there has hardly been any attempt to understand the social conditions within which such struggles play out, and are metamorphosed in turn. The effort in this paper is therefore to demonstrate (1) the nature of rural transformation brought about the process of urbanization in Rajarhat (which is demonstrative of similar processes across the country), and (2) explore how such transformations have also led to an evolving dichotomy along caste-lines, the emergent forms of economic engagements emanating from the rural transformation giving traditional caste-dynamics new forms of expression. The scant attention towards caste-relations in West Bengal in the mainstream literature-due to a rather limited electoral aggregation of caste interests (Sinharay 2012) -makes such forms more significant. However, this long-held political myth has recently come under some serious scrutiny via a series of works demonstrating the deep-rooted embeddedness of caste hierarchies in Bengali politics (Bandyopadhyay 2012; Samaddar 2013; Chatterjee 2012; Chandra, Heierstad and Nielsen 2015). This paper adds to this literature by deconstructing the Rajarhat story-interrogating both the land struggles and the implicit caste dimensions around the rural transformation. Methodologically, the paper is based on an exploratory ethnographic field research in Rajarhat. While a number of interviews (especially with the bureaucrats and political leaders) were conducted in Kolkata, the bulk of the fieldwork was spread across 10 sample villages (out of a total of 47), chosen on the basis of an even geographic spread across the entire area of Rajarhat. The story presented below emerges out of around 50 interviews conducted with villagers and farmers, bureaucrats, politicians and local political cadres, and syndicate members. Drawing on thematic content analysis and narrative analysis of the interview data, the story demonstrates the complex and contested dynamics at the ground level that usually remain unnoticed.

4 A final point needs to be made about the unique socio-political context of the state. Historically, West Bengal was an aberration-an island of political stability-amidst a rather chaotic Indian democracy. It was ruled by the Left Front (LF) government, a coalition of Left parties spearheaded by the Communist Party of India-Marxist (CPIM), uninterruptedly from 1977 to 2011. The CPIM/LF regime brought significant land 
reforms, as well as proper democratic decentralization via the panchayati-raj (a system of rural self-governance), and gained unprecedented popularity as a government for the poor. However, through the 1990s and early 2000s it gradually adopted a more promarket stance, pursuing a private-capital led industrialization agenda, which even led to the regime securing a historic majority in the 2006 state elections. However, it suffered steady electoral decline soon after, eventually capitulating to the main opposition party Trinamool Congress (TMC) in 2011. And it is precisely in the regime's final term that West Bengal also came to feature prominently in the context rural land struggles, the welldocumented Singur-Nandigram episodes being cases in point (Das 2016; Sarkar and Chowdhury 2009). Not only did Singur-Nandigram spark nationwide debates about the nature and legality of acquisition methods, but it also marked critical junctures in the state's political fortunes. The LF, having returned to power for an unprecedented seventh consecutive term in 2006, completely collapsed under the crisis that emerged from its high-handedness in acquiring farmland for private entrepreneurs in these two hamlets. It is this dichotomous backdrop against which the Rajarhat narrative needs to be told, one where private industrialization and neo-liberal urbanism was embraced by a regime having built its political capital as pro-poor and pro-farmer, and in a state that was a bastion of Marxist political forces for over three decades.

The paper is organized as follows: the next section, section two, provides a brief theoretical overview of the nature of rural transformation via land acquisition induced displacement-dispossession. Section three introduces the Rajarhat story, and brings the politics, socio-economic transformation and emergence of new forms of economic arrangements in the area (low-level cartels or "syndicates") to the fore. Section four shifts the focus to the largely overlooked aspects of caste-consciousness in Rajarhat, and examines how such consciousness found new expression in the transformative politics of the rural society.

\section{Theorizing Rural Transformation: Land Struggles and Social Dominance}

6 The structural shift in the value of land towards commodification (Akram-Lodhi 2007) and the state's transformation from an active promoter of public industries to a landbroker for private corporations (Levien 2013) are among the most notable effects of contemporary capitalist forces of accumulation. But while such effects of capitalist accumulation remain the focus of much of the literature on land, the process of dispossession-displacement also needs to be analytically fleshed out, the "means by which changes of land use and differential access take place and ... the varying forms of resistance or compliance by different groups and individuals over time" (Gardner and Gerharz 2016:2). ${ }^{1}$ In contemporary India/South Asia, for example, dispossession from land displays both a certain continuity and change in comparison to earlier periods (Adnan 2016). State-led acquisition, albeit age-old, continues to change significantly in purpose towards supplying land to private corporations. Moreover, the very notion of dispossession "implies a straightforward transfer of rights in which those that once possessed are dispossessed ... [but] the local realities ... are often far more nuanced, involving complex interrelationships between groups of users, legality, the state" (Gardner and Gerharz 2016:2). There is thus an evolving discussion about appropriate theoretical frameworks, especially building on Marx's concept of primitive accumulation 
(1976) and Harvey's (2003) conceptualization of "accumulation by dispossession" (ABD), alongside newer perspectives on market-driven processes of dispossession (AkramLodhi 2012), extra-economic coercion (Levien 2012), non-market transactions (Khan 2004), and voluntary processes based on persuasion, incentives, and temptation (Adnan 2016). Naturally, this discussion is often at analytical crossroads. However, such divergence only indicates the complexities involved in the local realities of land use, which in a sense is also the point of convergence amongst this varied literature, as its main aim remains to explore the nuanced and complex interrelationships between groups of users, legality, the state, and customary forms of access, cross cutting discourses of development, modernity, belonging and rights (Gardner and Gerharz 2016).

Most of these mechanisms are clearly at play across much of the developing nations. In India, however, what is interesting to note (but often overlooked) is how this fuzzy domain of displacement-dispossession allows traditional social forces (like caste) to reinvent/reassert themselves in newer forms. This is not necessarily a recent observation, but one that tends to get glossed over in the more procedural and legislative criticisms of land acquisition. An affirmation of this observation can, however, be found in Le Mons Walker's (2008) seminal work on neoliberalism on the ground in rural India. As a strategy of capital accumulation, she writes, the neoliberal project has revolved crucially around the transfer of property and land use rights, and the exclusion of massive numbers of rural people from the accumulation process:

To the extent that their exclusion has been achieved through expropriation and dispossession, it has formed the basis not only for the transfer of property and property rights, but also in many if not most instances for the swelling of the ranks ... of a "reserve army" of cheap expendable labour-another key component of the neoliberal accumulation strategy. (Walker 2008:605)

State-based land seizures, the dispossession of significant numbers of the rural poor, and the agrarian conflict they have engendered have been key features of the playing out of neoliberalism in the Indian countryside. She further observes:

These conflicts reflect state policies that underpinned and contributed to agrarian deterioration and crisis. The dominant classes, including both larger higher-caste and intermediate landholders, responded by attempting to preserve their social positions and modes of accumulation by thwarting the attempts of poorer peasants and rural laborers to improve their livelihoods. The initiatives of these classes have included both economic devices and extra-economic coercion, and in many instances they have produced as well a new unity and "closing of the ranks" among the landholders. (Walker 2008:595)

There are various examples of such high-caste dominance, from the use of private armies by upper-caste landlords in Bihar to caste based atrocities on agricultural laborers by landholders in Tamil Nadu. As Le Mons Walker argues further, in a neoliberal context, such new forms of violence (often in the shape of caste-based atrocities) form the political and social corollary to the economic internal colonization of the poor (Walker 2008:595). Therefore, the reconfiguration of caste relations as a result of contemporary land struggles and how such struggles themselves are being shaped through traditional castebased hierarchies, are both important areas to explore. The Rajarhat story is a prime example of this. While theoretical constructs such as ABD, market-led forces of dispossession around land struggle, etc. give this paper its analytical grounding and connect to the wider phenomenon of capitalist accumulation, the challenge is to make sense of such associated reconfigurations of social dynamics on the ground. 


\section{Displacement, Rural Transformation, and Rise of the Syndicate-Raj in Rajarhat}

Kolkata, the capital of West Bengal, is often characterized as "the city that got left behind" (Anon 2012). Since 1977, while the LF (and particularly the CPIM) consolidated itself politically via the twin measures of land reforms and panchayati raj-along with a series of political maneuvers that allowed the "party" to entrench itself as a hegemonic entity in every state institution-the industrial fortunes of West Bengal had continued to dwindle. Riddled with stagnant industrialization, gradual loss of urban political ground, and dire infrastructural conditions (Das and Mahmood 2015), the LF took up the mantle of urban development by early 1990, which became the primary catalyst in its attempt at an economic rejuvenation. The government aggressively sought to transform Calcutta into a world-class city, following the "predictable formula of elite enclaves of residence and leisure, economic zones ... and civic campaigns to insure beauty and order" (Roy 2011:259). The Kolkata new town project, located in the Rajarhat area on the northeastern fringes of the city, was its premier program: a self-contained, environmentfriendly planned settlement to ease Kolkata's population pressure, and also a major business and IT hub, under the aegis of the West Bengal Housing and Industrial Development Corporation or HIDCO (HIDCO 1999).

Geographically, the entire Rajarhat block amounted to an area of $107.87 \mathrm{sq} . \mathrm{km}$, and had 47 inhabited villages, 54523 households, and a net population of 417192 (mostly low-caste and Muslims, see Table 4) by 2001 (District Statistical Handbook 2003). The entire block was divided into 55 mouzas, ${ }^{2} 25$ of which were initially notified for acquisition in accordance with the Land Acquisition Act of $1894 .^{3}$ As per the first land use plan (HIDCO 1995), the total Rajarhat project area was 2750 hectares, allocation of land being as follows: $30.5 \%$ residential, $7.3 \%$ industrial, 5.5 percent commercial, 1.1 percent social/ educational/healthcare facilities, 8.8 percent roads/transportation, and 47.6 percent open space. Following several revisions, by 2010 the allocations were: 41.77 percent residential, 0.23 percent industrial, 5 percent IT services, 11 percent commercial, 8 percent social facilities, 12 percent transportation, and 22 percent open spaces (Mukherjee 2016). ${ }^{4}$ Contrary to initial objectives, Rajarhat thus gradually emerged not as an industrial or commercial hub, but a largely residential settlement. The area is now primarily divided into Action Areas I (677 hectares), II (1310 hectares) and III (783 hectares), designed to accommodate approximately 1 million people, along with another 0.5 million from the floating population (HIDCO 2012). However, behind the story of successful urban development remained a plethora of conflicting elements, demonstrating the fuzzy terrain of development-displacement at Rajarhat. In particular, there are three issues that need elaboration.

The first is the issue of limited compensation and the violent nature of displacement. As per one estimate, most of the land was acquired for Rs. 300,000/acre, almost half the market price of Rs. 600,000 (Johnson and Chakravarty 2013). Another estimate is that HIDCO purchased land at Rs. 5-6,000/ $\mathrm{katha}^{5}$ against the officially registered rate of Rs. 450,000 (Sengupta 2008), selling it within a year or two at Rs. 60,000/katha, and even at Rs. $200,000 /$ katha (Johnson and Chakravarty 2013). What is more intriguing though, is the nature of displacement in Rajarhat. In 1999, the government published a report titled: 
"Report of the Rehabilitation and Resettlement Committee for Project Affected People (PAP) of New Town Project." It read:

A unique feature of this project [is] ... a continuous dialogue between the PAP and the project authorities ... Consent of the PAP was obtained through discussions and meetings. As a result the project has not been so far plagued with court cases and litigation ... The pro-people attitude taken by the project authorities and the Govt. should be emulated in other projects (GoWB 1999:5).

Compare this with the following excerpt from an investigative report published by The Sanhati Collective.

The CPI(M) party leadership went on a land grabbing spree with the active collusion of the local police and administration. Poor people fearful for their lives were forced to sign off their land at gunpoint ... the whole area was under the grip of fear and terror ... Those who were unwilling to give up their land ... were subject to unmentionable strong-arm tactics. Many left hearth and home because of beatings and harassment. Those who reported to the police were murdered. (Sengupta 2008:4)

The two versions could not be more different. And while the second is a rather dystopian account, tales of land grab, intimidation, and violence are not uncommon in Rajarhat. A Nagarik Mancha ${ }^{6}$ publication, for example, notes that "land sharks became immediately active in the area. Forceful land grabbing and dispossession also escalated rapidly. Buying land in very low price, they later sold it at much higher rates ... More than 50 people are estimated to have been murdered in Rajarhat" (Dey 2011:6-8; author's translation from Bengali). Similar anecdotes, stories, and memories can still be heard aplenty if one enters the remnants of erstwhile rural settlements in the area, demonstrating how "land [was] looted from the local villagers ... the empty fields there represent[ing] ... the death of agriculture ... its murder by capital, the savage commodification of land, and the resurgence of private property in the city" (Dey, Samaddar and Sen 2013:19-20; emphasis added). Once again, it is interesting that such high levels of disruption in an area with a 50 percent lowcaste and Muslim population still did not lead to any direct caste based mobilization, something that would have been the expected course of events in most other states.

The second issue that needs to be addressed is the extent of transformation in rural livelihood. What is the condition of these villages today? They continue to exist, but in a severely constricted manner, as the development of the city required all the cultivable land around each village, with only the habitational parts left out. Engulfed within the urban sectors, remnants of these villages are euphemistically referred to as urban villages (somewhat developed with better road connectivity with the urban sections). However, irrespective of the euphemism, and despite several promises by HIDCO to undertake necessary developmental work, there remains a stark contrast between the posh urban enclaves and the sorry state of the villages, which have essentially become extremely dense living quarters with burgeoning populations, but with hardly any public spaces, along with choked sewage systems, narrow roads, and unsafe residential structures.

Having lost their agricultural livelihoods, the primary occupation of the villagers is to rent out low-cost accommodation to migrant workers, daily wagers, small-scale businessmen, or do odd jobs as masons, drivers, carpenters, security guards, and housemaids. This is reflected in the following tables that document the rapidly reducing farming opportunities in the area post-2000. Table 1 demonstrates the reduction in the farming population from 2001-2004 when the Rajarhat project was in full swing; Table 2 shows the rapid fall in the net area under cultivation from 1996 onwards; and Table 3 documents the concomitant stagnation of agricultural, manufacturing workforces and a 
rise in the "other"' category, which comprises of such small jobs (masons, drivers, guards, etc.). Additionally, the government had promised to rehabilitate all evicted families and to train and give employment to at least one family member. But a Comptroller and Auditor General (CAG) report in 2007 noted that only 2691 individuals had been trained, along with 47 cooperative societies and 56 self-help groups set up with just 3073 landowners. In fact, "even after a lapse of eight years, [HIDCO] had rehabilitated only 17 percent of identified project affected families ... and failed to identify the remaining erstwhile landowners" (CAG 2007:27).7

Table 1: Changes in Farming Population in Rajarhat (2001-04)

\begin{tabular}{|l|l|l|}
\hline Year & Small farmers & Marginal farmers \\
\hline $2001-02$ & 12,105 & 6,170 \\
\hline $2002-03$ & 21,417 & 6,232 \\
\hline $2003-04$ & 10 & 3,890 \\
\hline
\end{tabular}

Source: District Statistical Handbooks (2002-2004)

Table 2: Land Distribution in Rajarhat (1996-2003)

\begin{tabular}{|l|l|l|}
\hline Year & $\begin{array}{l}\text { Net Area Under Cultivation (in } \\
\text { hectares) }\end{array}$ & $\begin{array}{l}\text { Area Under Pasture and Orchard (in } \\
\text { hectares) }\end{array}$ \\
\hline 1997 & $7,964.07$ & 183.53 \\
\hline $\begin{array}{l}1998-2001 \\
8\end{array}$ & 3,958 & 453 \\
\hline 2002 & 3,911 & 453 \\
\hline 2003 & $1,601.8$ & 183.33 \\
\hline
\end{tabular}

Source: District Statistical Handbooks (1997-2004)

Table 3: Percentage Distribution of Workforce Population (2002-2004)

\begin{tabular}{|l|l|l|l|l|l|l|l|l|}
\hline Year & \multicolumn{3}{|l|}{ Cultivators } & \multicolumn{2}{l|}{$\begin{array}{l}\text { Agricultural } \\
\text { Laborers }\end{array}$} & \multicolumn{2}{l|}{$\begin{array}{l}\text { Household } \\
\text { workers }\end{array}$} \\
\hline & Rural & Urban & Rural & Urban & Rural & Urban & Rural & Urban \\
\hline 2002 & 2.69 & 0.03 & 4.93 & 0.07 & 1.68 & 0.51 & 20.88 & 33.74 \\
\hline 2004 & 9.7 & 0.6 & 16.4 & 0.3 & 5.8 & 1.7 & 68.1 & 97.4 \\
\hline
\end{tabular}


13 The third and final issue which needs to be explored is the emergence of new forms of economic engagement in the area: in particular, what is commonly referred to as the syndicate-raj. Rajarhat today is synonymous with "syndicates," described in a recent news article as "Kolkata's open secret of extortion rackets" (Anon 2016). Syndicates are essentially low-level cartels that have gradually turned into "businesses" offering "services like purchase of land, supply of building materials and engagement of laborers to builders and property developers ... extort[ing] money from petty shopkeepers, owners of small and medium industrial units and others" (CAG 2007:25). Although consolidated during the TMC government, the rise of the syndicates can be traced back to the last decade of the LF rule. In the absence of industrial investment and the much promised jobs, CPIM leaders decided to award a form of political compensation to the dispossessed, allocating (informal) contracts to local youth for providing construction material in their neighborhoods. Gautam Deb (Housing Minister of the LF and the chief architect of Rajarhat) personally oversaw the proceedings. As he recalls:

I made sure that the local youth got necessary financial assistance and permits for driving trucks, which I then hired back for construction/land-filling purposes. I also instructed that HIDCO gave them all the small jobs-supplying material, building walls/fences and small pathways, planting trees, and also supplying labour if required. We adjusted the system itself in order to accommodate such ventures. ${ }^{9}$

While this could have been an innovative business model to generate employment, on the ground it turned entirely into a party-mediated exercise. The CPIM local committees were in charge of deciding to whom the contracts should be awarded in their respective areas, and in most cases contracts went to party-affiliated individuals (Johnson and Chakravarty 2013). This also gave rise to a certain form of rent-seeking, as a share of the payments had to be paid back to local party elites, ensuring necessary political protection and insulation from law-enforcing agencies (Roy 2016).

It is, however, during the TMC rule that the syndicates have flourished, becoming an almost indispensable political force. Before the 2016 state election, the current Rajarhat TMC MLA Sabyasachi Dutta was quoted as saying that he has 20,000 people working for him, a TMC "army that keeps the syndicate machinery rolling and moonlights as the vote mafia during elections" (Banerjee and Sengupta 2016). He further claimed:

If there is no syndicate, 20,000 people will die of starvation, the government will fall. If I tell 20,000 people that you have to starve to death, even if 2,000 goons die among them it would be a major crisis ... Defeating me is not simply difficult, it's impossible (Roy 2016:24).

A senior TMC member, on conditions of anonymity, described the scale of the problem: Currently there are about 270 operational syndicates, with connections right up to the ministry. They broadly operate under two parallel authority umbrellas, controlled directly by two cabinet ministers. The daily collection of all the syndicates is more than half a million. The chief minister is aware of the problem, but given the money and people involved, it is an untouchable system. ${ }^{10}$

\section{The Reproduction of Caste Relations in Rajarhat}

15 Let us now turn to the core question of the story: how did the fuzzy domain of displacement-dispossession at Rajarhat allow traditional caste dynamics in the villages to reinvent and reassert themselves in newer forms? Answering this is a challenging task, as no caste based mobilization had coalesced in Rajarhat. This is not entirely unexpected owing to the exceptionalism of West Bengal, where caste has been notoriously 
understudied owing to its very distinctive political history. Neither during the early decades of Congress rule or the LF was caste a strategy of electoral mobilization, nor has there been a major caste-based social movement in the state. This is particularly noteworthy in the wider context of much more direct on ground caste dynamics in most other states, where the political discourses have historically been framed along explicit caste lines. However, as Chandra and Nielsen (2012) point out, if one looks beyond aggregate election data, caste does emerge as an important indicator of popular political behavior in the state. ${ }^{11}$ But it is undeniable that a prolonged Left hegemony has led somewhat to the ideological subsumption of caste by class, ostensibly underpinned by loyalties forged "across divisions of caste and community" (Chatterjee 1997:69); and the conspicuous socio-political dominance of the self-professed "casteless" Bengali bhadralok ${ }^{12}$ (Tawa Lama-Rewal 2009).

Contextualizing the Rajarhat story against such a backdrop poses a dual challenge. While Rajarhat has been in news in light of the recent land acquisition strife in West Bengal, the caste question has barely received any attention. And even if this is attributed to the scant historical attention towards Bengali caste politics, the unfolding of events on the ground did not follow caste lines either. Yet, it is this challenge that also raises an intriguing dialectic. How does the salience of caste hierarchies continue to inform everyday politics and structure political action, while reproducing its own invisibility at every turn? This is probably the most intriguing outcome of the extent of the transformation witnessed in the villages of Rajarhat.

\section{The Spatiality of Caste in Rajarhat Villages}

Despite a conspicuous absence from political discourses, caste remains highly visible in Rajarhat. This is noticeable in the population demography of the area itself, Dalits and Muslims being the two predominant groups. In fact, they made up more than 50 per cent of the entire population in 2003, and remain at around 40 per cent according to the 2011 census data (see Table 4). Across the 10 villages where the fieldwork was conducted, Namasudra was clearly the most prominent caste, followed by Bagdi, Bhuimali, and (a few households of) Hari.

Table 4: Dalit and Muslim Population in Rajarhat $(2001-2003,2011)^{13}$

\begin{tabular}{|l|l|l|l|}
\hline Year & Total Population & Schedule Castes & Muslims \\
\hline 2001 & 417,192 & $87,907(21.07 \%)$ & $109,504(26.24 \%)$ \\
\hline 2003 & 417,192 & $102,867(24.66 \%)$ & - do- \\
\hline 2011 & 592,737 & $141,513(23.87 \%)$ & $100,024(16 \%)$ \\
\hline
\end{tabular}

Source: District Statistical Handbooks (2002, 2004, 2013)

In most villages, the spatiality of caste stands out, as there are distinct segregations between lower and upper-caste habitations, a fairly common phenomenon in West Bengal villages, also noted by authors such as Roy (2012). The upper caste locations are usually referred to as Bamun-para (locality of the Brahmins), or sometimes even identified by 
specific surnames such as Chakrabarty-para or Ray-para (Chakrabarty and Ray being uppercaste surnames). The lower caste locations are relatively mixed, with people from Namasudras, Bhuimali, Bagdi and other low castes living side by side. Interestingly, in a number of villages these areas are commonly addressed as the purono-para (the old locality), possibly indicative of the low-castes being the original inhabitants. There are some instances of specific caste-named localities, such as Bagdi-para (locality of the Bagdi caste), Sardar-para, and so on. Another name is also quite common in several villages: notun-para (the new locality). These areas are usually located at the village peripheries and are relatively new. The caste profile is fairly mixed and the houses are mostly rented out to outsiders who work in the neighboring apartments or offices. The religious segregation is, however, even starker, as the Muslim areas are very clearly demarcated, usually known as the Molla-para (locality of the Muslims, Molla being the most common Muslim surname in Rajarhat).

19 The following conversation with an old resident of Bamun-para in Aatghora village is very clearly indicative of these segregations. Notice how the importance of the Bamun-para is projected in relation to the nearest skyscraper.

My forefathers lived in this Bamun-para. My entire life has been spent here. Further down this road is Mandal-para [locality of the Mandals]. There is a small market after Mandal-para, the last shop being a butcher's. The Molla-para starts after that. We go up to the butcher's shop, but usually don't go beyond. The Bamun-para is right at the centre of the village though. There's a big tower only at a stone's throw. ${ }^{14}$

The spatial segregation is reinforced by a clear economic stratification. There is a difference in the condition of the houses in the upper-caste hamlets and they are noticeably more affluent. A typical Bamun-para house is more spacious, brightly painted, has a courtyard, a boundary wall, and is usually two-to-three storied. Houses in the lower-caste hamlets are much smaller in comparison, mostly one-storied, sparsely painted, and the localities are a lot more congested. Another noticeable difference is in the workforce pattern. In Patharghata mouza, for example, there are only a handful of upper-caste houses in the middle of the village, with at least one member in each family with a permanent job, some being government employees as well. In contrast, the rest of the villagers are mostly doing small odd jobs or are self-employed. Anecdotes aplenty can also be heard about upper-caste families having received substantial compensation as opposed to the residents in other areas, indicating that the former owned comparatively larger quantities of land.

\section{The Emergent Bhadralok-Borolok-Chhotolok Tripartite and the Syndicate-Raj}

So how did such caste-consciousness play out in the context of the rural transformation? Upon conversing with the villagers, it became evident that there is a strong sense of frustration among large sections, having lost their permanent income source and having not received the promised benefits. Such feelings are directed both towards the government, and also a section of the local elites with close proximity to the CPIM. This, on the surface, plays out more in class terms: boro-lok (the big or rich people) vs gorib-lok (the poor people), the most common sentiment heard across villages being:

The borolok had their party connections, and some made enormous profits overnight. It's only the gorib-lok whose conditions have steadily deteriorated. ${ }^{15}$ 
Within a village, people are normally known to each other, and thereby the resentment towards the borolok was specifically directed: the residents of this house here, the members of that family there, or the owner of this shop or those new buildings-were clearly identified as those with party-connections or even party members. Many such conversations in the villages took the shape of expressing frustration towards the borolok for having exploited the system and for the gorib-lok being left behind, couched in the class-terms that are taken to be characteristic of common parlance in the countryside. However, in the overusage of this typology, what often remain ignored are the multiple meanings and overlapping signaling of class as well as caste relations. It needs to be understood-and this is probably unique to West Bengal given the historic prominence of class in the political discourse and yet underlying patterns of social organization along caste linesthat there is a continuous interchange of class and caste identities in common parlance. A clear hint at this interchangeability came from a conversation with Mahesh Dhali, a dispossessed farmer running a tea-stall in Patharghata:

So what they are borolok? It's only because they were close to the party that they became borolok overnight. But that doesn't mean they have become bhadralok. They are still the chhotolok that they always were..$^{16}$

This is a rather insightful statement. Upon pursuing a similar line of questioning, several such responses were heard: a borolok for only two days can't be a bhadralok; they might have money, but they are chhotolok like us only, ${ }^{17}$ and so on.

So what does this borolok-chhotolok-bhadralok tripartite imply? Here it is important to recognize that these terms are not usually taken to be indicative of caste-identities, and are in fact mostly used to indicate class-relations. The terms do not engage directly in defining what caste is (jati, varna) or used to be. Instead, as Chandra, et al. (2015:2) point out in their attempt to situate West Bengal exceptionalism, "caste implies different things to different people at different times, and that caste is used politically in different ways". In the same vein, and in the context of socio-economic changes brought by the fuzzy domain of displacement-dispossession in Rajarhat, the terms borolok-bhadralok-chhotolok have come to assume a multitude of meanings-interchanging between class and caste lines-unpacking which can give us insights into the changing caste dynamics. The term borolok is used to indicate the economically nouveau rich (so a class-term), but is also used to indicate a degree of differentiation from the bhadralok in terms of the borolok's lower status in the social hierarchy (so a caste-term). There is a distinction between those who became economically affluent over the course of the project but come from a lower social stratum (the overnight borolok) and the traditionally or socially affluent (the bhadralok), as the higher social status of the bhadralok cannot be replaced by economic affluence alone. Even if the borolok is economically better off than the bhadralok, the latter continues to enjoy a higher social standing (therefore caste identity is far more entrenched than class). There are of course those who are bhadralok as well as borolok, and they are usually wellrespected. The term chhotolok, on the other hand, directly indicates a low-caste origin, and when used in conjunction with borolok, it is the caste relation that is being implied, and not class. Referring to the Bamun-para residents of his village, Mahesh Dhali made a very incisive comment that uses all these terms with the multiplicity of meanings:

They are bhadralok, of course they will be borolok as well. But can the borolok become bhadralok just by having money? Family, tradition, education-where will the chhotolok get these from ${ }^{18}$

This is a key comment, playing with the multiplicity in meanings. In the first sentence, the bhadralok (high caste) is expected to be a borolok as well. Here borolok is being used in a 
class sense (economic richness), as the higher social standing of the bhadralok is expected to translate into greater economic affluence as well. But in the second sentence, borolok takes on a caste-meaning. Gains made in class-terms alone are not enough to alleviate the low social status of the borolok (they cannot gain the respect of the high castes just by having money). In the third line, the distinction is made even more explicit, when it is said that the borolok is hardly any different from the chhotolok (the low-castes), as the economic gains of the former (progress made in class-terms) can hardly be a substitute for the social capital of the traditional high castes, i.e. the bhadralok.

This is how caste-consciousness has found new forms of expression in Rajarhat villages. Among the dispossessed, the lower-castes and the Muslims were at a particular disadvantage given their lack of economic and social capital. But the surrounding urbanization has brought certain economic opportunities for those close to the party (particularly through "syndicates"), and in almost every village there were groups of young men-largely low caste and Muslims-who did gain quick financial benefits from the urbanization process. But their rapid economic affluence could not elevate them to the bhadralok status. They became borolok (used in a class-sense, indicating economic richness), but remained chhotolok (low caste) at the same time, as their riches were not a substitute for heritage and tradition. Most villages in Rajarhat now have three groups of people: the upper-caste bhadralok (most of whom are also borolok, as they are expected to be), the ones who became borolok during the course of the project (who progressed in class terms but not caste), and the chhotolok who continue in poverty (the archetypical low-caste). The Bengali political tradition ensures that the bhadralok continues to be respected for their social/cultural capital and upper-caste heritage, and even if economically stronger, the lower-caste borolok cannot escape from their chhotolok status in the absence of that heritage. ${ }^{19}$

Now, this tripartite terminology has another crucial dimension if one examines the rise of the syndicate-raj in Rajarhat. Although widespread, syndicates are notoriously difficult to talk to in the villages of Rajarhat. It was only after a month in the field that access could be gained, and under conditions of strict anonymity. While reluctant to divulge information about their operational structures and political linkages, the implicit caste aspects-or more specifically, the bhadralok-borolok-chhotolok dynamics-were freely discussed. Among the syndicates that could be observed, it was fairly obvious that membership was largely drawn from lower-castes and Muslim youth. Among all the syndicates observed/interacted with, hardly any were members of the upper castes, the Namasudra and Bagdi castes being the most prominent. This is perhaps not surprising given the overall demography of Rajarhat, but the leadership was also reflective of this trend. There are two local leaders-Bhajai Sardar and Aftabuddin-each controlling roughly 135 syndicates, the former a low-caste Hindu, the latter a Muslim. The overall number and size of syndicates in Rajarhat have steadily risen since the CPIM days and strengthened significantly in the TMC era, but the membership character has not changed much, attracting unemployed youth (almost exclusively male) from the minorities.

24 The obvious financial opportunities aside, what else motivates a youth to join a syndicate? The leader of a small syndicate explained:

of course there's the money. But more important is ijjat (respect). We had no ijjat in the village. We were born chhotolok, and would have remained so had it not been for 
the syndicate. Today I have 12 people working for me, I have political connections.

Even village elders talk to me with respect. ${ }^{20}$

Similar sentiments were echoed by several syndicate members. A relatively new and young recruit of a big syndicate admitted:

I have only studied till $8^{\text {th }}$ standard. There was no steady income in the family. My

brother drives an autorickshaw. But now I have a good lifestyle. I will also have

connections and meet important people. No one will look down on me anymore. ${ }^{21}$

Alongside quick money, it is the search for ijjat that leads young men to join syndicates. The most insightful comment came, however, not from a syndicate member, but from the mother of a syndicate member. Upon asking why she allowed her son to join an illegal business, she responded:

What has the law done for us? They gave us a pittance in the name of compensation, and now our land is worth millions. We can never be like those bhadralok living in our land, but if my son earns money, we can escape a chhotolok's life. ${ }^{22}$

Thus we return to the tripartite terminology again. Besides quick money and an exciting lifestyle, the syndicate-raj (as it is referred to in the media, the syndicates being the real power-brokers locally) seems to have provided an avenue for the aspirations of the lowercastes, be it for respect, or at least to escape the entrapments of being a chhotolok. The upper-caste bhadralok heritage will remain elusive for most, but at least they can climb the social ladder to some degree and be a borolok.

\section{Conclusion}

The multiple narratives around Rajarhat indicate a qualitative shift in the politics of the rural. As the old politics of citizenship withers away in the villages with the increasing penetration of market forces, a new politics is being produced via the interaction of a ubiquitous neoliberal development with its collateral, the multitude of dispossessed and disenfranchised. A point can be raised about whether this politics is significantly indicative of a transforming rural, or is just a continuation of similar trends in urban/ peri-urban areas, and there are indeed linkages between the two. However, the Rajarhat story reflects traits that are both distinctive and also link to changes witnessed across rural India. On the one hand, given the West Bengal exceptionalism as far as caste-based mobilization is concerned, the shifting dynamics brought by the new town project points to the regional specificity of the story. One the other hand, first, the large scale capitalist expropriation of land is undeniably changing the rural like never before, and yet the "development" processes that engulf rural societies promising urban regeneration tend to bypass the dispossessed. As the rapidly deteriorated farming conditions in Rajarhat demonstrate, such processes create their own wasteland-the social space of a dispossessed labor force-thereby reshaping and restructuring rural-urban relations in post-colonial societies (Bhattacharya and Sanyal 2011). Second, there is underlying violent nature of this expropriation. The tactics used by the CPIM to capture land is symptomatic of what Le Mons Walker (2008) identifies to be a key trend in the countryside: the use of officially sanctioned criminal violence at the level of the state and by private landholders against the rural poor. In a neoliberal context, that violence forms the political and social corollary to the economic internal colonization of the poor. Third, there is the changing nature of rural proletariat. Given the continuing farmer resistance to dispossession across the country, the agrarian questions of labor and capital are, consequently, now re-joined in the land question, amplifying existing inequalities in 
novel ways (Levien 2012). The rise of syndicates and the renewed caste dynamics are reflective of what Levien describes as the involutionary dynamic of agrarian change that is ultimately impoverishing for the rural poor (Levin 2012; see also Agarwal and Levien 2019). In Rajarhat, the dispossessed cannot look to this new "development" with desire, but they cannot abandon it either, thereby ending up negotiating new forms of political adjustment. There remains a memory, but there is nothing in the present that one identifies with, the dispossession thus not only being from economic means, but also from identity. Ranjit Nashkar, an elderly inhabitant of Patharghata, evocatively recalled:

I used to live in Patharghata, went to school in Kochpukur, and used to play in that field next to the Talpukur pond. But no one recognises these names anymore. Instead, I am a resident of Action Area II. They have erased my existence, my identity, and also that of my forefathers. Not only is my land gone, but so are my memories. $^{23}$

The role of the state in enacting this transformation in the villages, the concomitant displacement, marginalization, and newer forms of socio-economic engagements also define these politics. Displacement is "constructed" by the state, its institutions, political entities, local actors and networks, a trend not only evident in Rajarhat, but across India, and indeed across the global South. The politics thus need to be looked for in this process of construction, and in the relation between what it produces and leaves behind. This paper has tried to explore this relation in the rural vestiges left behind by the urbanization process in Rajarhat, as it brought about large scale displacementdispossession and rapid socio-economic changes in rural lives. The caste perspective, in turn, while adding to the debate on the relevance of caste consciousness in a bhadralok dominated Bengali society, also symbolizes this relationship. The paper refrains from claiming any direct causal link between the displacement narratives and the reoriented caste-dynamics. The relationship between the two is often multifaceted and is expressed differently in different parts of the country. However, at least two types of analytical linkages weave the various parts of the Rajarhat story together. First, Rajarhat is demonstrative of how processes of capitalist accumulation can lead to caste-relations being simultaneously reinvented and redeployed in a rapidly transforming rural society in newer forms. Second, the story also shows how the new economic arrangements that emerge as a result of such accumulation and transformation can both aid this reinvention, while also reinforcing new forms of stratification. The duality of this relational politics, in this sense, is in the way the modern (the transforming rural economy as a result of rapid urbanization) cohabits with the traditional (the social hierarchies), and is legitimized by it.

It is this cohabitation and legitimization that symbolizes not only the core conflict of Rajarhat, but also that of contemporary rural societies in India. The unique nature of West Bengal-the political stability of the LF as well as the domination of the casteless bhadralok -does make it a rather special case among the chaotic Indian democracy. But what the Rajarhat story also signals in a broader sense is the overwhelming transformations that Indian rural society has undergone over the last few decades, the changing power relationships and the consequences, the heterogeneity of Indian rural social space, its stratification and deeply entrenched economic and social divisions. The economic stratification induced by displacement-dispossession often reinforces the traditional social hierarchies where the upper caste with social and economic capital emerges as the primary beneficiary of "development". In Rajarhat, the importance of achieving the bhadralok status, or at least a borolok, is rooted in an economic dispossession that has 
reasserted the social entrapments of being a chhotolok. Robbed of their legitimate socioeconomic relations of production on the one hand and their memories and identity on the other, the chhotolok is now in a perpetual search for both sustenance and ijjat (respect). The cross-cutting themes of displacement, dispossession, identity, and social hierarchies are thereby symbolic of the heterogeneous and unequal stratification that are blatantly evident across the Indian countryside. Albeit often side-lined in the global city/ urbanization discourses and the broader debates about the neoliberal onslaught, it is important to recognize and unpack-as this volume aptly demonstrates-this stratification and the transformative processes in rural societies and livelihood.

\section{BIBLIOGRAPHY}

Agarwal, Samantha and Michael Levien. 2019. "Dalits and Dispossession: A Comparison." Journal of Contemporary Asia Retrieved April 1, 2019 (https://doi.org/10.1080/00472336.2019.1597145).

Akram-Lodhi, Haroon. 2012. "Contextualizing Land Grabbing: Contemporary Land Deals, the Global Subsistence Crisis and the World Food System." Canadian Journal of Development Studies 33 (2):119-42.

Akram-Lodhi, Haroon. 2009. "Modernising Subordination? A South Asian Perspective on the World Development Report 2008: Agriculture for Development." Journal of Peasant Studies 36 (3):611-19.

Akram-Lodhi, Haroon. 2007. "Land, Markets and Neo-liberal Enclosure: An Agrarian Political Economy Perspective.” Third World Quarterly 28(8):1437-56.

Adnan, Shapan. 2016. "Alienation in Neo-liberal India and Bangladesh: Diversity of Mechanisms and Theoretical Implications." South Asia Multidisciplinary Academic Journal 13. Retrieved April 3, 2019 (http://samaj.revues.org/4130).

Adnan, Shapan. 2015. "Primitive Accumulation and the 'Transition to Capitalism' in Neo-liberal India: Mechanisms, Resistance and the Persistence of Self-employed Labour." Pp. 23-54 in Indian Capitalism in Development, edited by B. Harriss-White and J. Heyer. London and New York: Routledge.

Adnan, Shapan. 2013. "Land Grabs and Primitive Accumulation in Deltaic Bangladesh: Interactions between Neo-liberal Globalization, State Interventions, Power Relations and Peasant Resistance." Journal of Peasant Studies 40(1):87-128.

Anon. 2016. "Flourishing 'Syndicate Raj' Is an Open Secret in Bengal." Hindustan Times, April 7. Retrieved April 102019 (http://www.hindustantimes.com/assembly-elections/flourishingsyndicate-raj-is-an-open-secret-in-bengal/story-WoDYZCYhnPJ6whzXahrHPJ.html).

Anon. 2012. "Reviving Kolkata: The City that Got Left Behind." The Economist, January 7. Retrieved July 6, 2019 (https://www.economist.com/asia/2012/01/07/the-city-that-got-left-behind).

Bandyopadhyay, Sarbani. 2012. "Caste and Politics in Bengal." Economic and Political Weekly 47 (50):71-73.

Bandyopadhyay, Sarbani. 1990. Caste, Politics and the Raj: Bengal 1872-1937. Calcutta: K. P. Bagchi. 
Banerjee, Mukulika. 2015. "Forward." Pp. xi-xii in The Politics of Caste in West Bengal, edited by U. Chandra, G. Heierstad, and K. B. Nielsen. Oxford: Routledge.

Banerjee, Mukulika. 2010. "Leadership and Political Work." Pp. 20-43 in Power and Influence in India: Bosses, Lords, and Captains, edited by P. Price and A. Ruud. New Delhi: Routledge.

Banerjee, Tamaghna and Snehal Sengupta. 2016. "Sorry on Lips, Army of Syndicates Draws up Stop-voter Plan.” The Telegraph, April 23. Retrieved July 6, 2019 (https:// www.telegraphindia.com/states/west-bengal/sorry-on-lips-army-of-syndicates-draws-up-stopvoter-plan/cid/1502161).

Bedi, Heather Plumridge. 2015. "Judicial Justice for Special Economic Zone Land Resistance." Journal of Contemporary Asia 45(4):596-617.

Bhattacharyya, Dwaipayan. 2016. Government as Practice: Democratic Left in a Transforming India. New Delhi: Cambridge University Press.

Bhattacharya, Rajesh and Kalyan Sanyal. 2011. "Bypassing the Squalor: New Towns, Immaterial Labour and Exclusion in Post-colonial Urbanisation." Economic and Political Weekly XLVI(31):41-48.

Bose, Pablo. 2013. "Bourgeoisie Environmentalism, Leftist Development and Neo-liberal Urbanism in the City of Joy." Pp. 127-53 in Locating Right to the City in the Global South, edited by T. R. Samara, S. He, and G. Chen. Oxford: Routledge.

Breman, Jan. 2007. The Jan Breman Omnibus. New Delhi: Oxford University Press.

CAG. 2007. Performance Reviews Relating to Government Companies: West Bengal Housing Infrastructure Development Organisation Ltd. Retrieved July 17, 2019 (http://www.cag.gov.in/sites/default/files/ old_reports/state/West_Bengal/2007/Commercial/com_chap_2.pdf).

Cernea, Michael. 2016. "Foreword: State Legislation Facing Involuntary Resettlement: Comparing the Thinking in China and India on Development-Displacement." Pp. vii-lii, Development-induced Displacement in India and China: A Comparative Look at the Burdens of Growth, edited by F. Padovani. Lanham: Lexington Books.

Cernea, Michael. 2006. “Re-examining 'Displacement': A Redefinition of Concepts in Development and Conservation Policies." Social Change 36(1):8-35.

Chandra, Uday, Geir Heierstad, and Kenneth Bo Nielsen, eds. 2015. The Politics of Caste in West Bengal. Oxford: Routledge.

Chandra, Uday, and Kenneth Bo Nielsen. 2012. "The Importance of Caste in Bengal.” Economic and Political Weekly 47(44):59-61.

Chen, Xiangming, Lan Wang, and Ratoola Kundu. 2009. "Localizing the Production of Global Cities: A Comparison of New Town Developments Around Shanghai and Kolkata." City \& Community 8(4):433-65.

Chatterjee, Partha. 1997. The Present History of West Bengal: Essays in Political Criticism. New Delhi: Oxford University Press.

Chatterjee, Partha. 2012. "Historicising Caste in Bengal Politics." Economic and Political Weekly 47 (50):69-70.

Chatterjee, Partha. 1989. “Caste and Subaltern Consciousness.” Pp. 169-209 in Subaltern Studies VI, edited by R. Guha. New Delhi: Oxford University Press.

Cross, Jamie. 2014. Dream Zones: Anticipating Capitalism and Development in India. London: Pluto Press. 
Das, Ritanjan. 2016. "The Politics of Land, Consent, and Negotiation: Revisiting the DevelopmentDisplacement Narratives from Singur in West Bengal." South Asia Multidisciplinary Academic Journal 13. Retrieved April 8, 2019 (http://samaj.revues.org/4103).

Das, Ritanjan and Zaad Mahmood. 2015. "Contradictions, Negotiations and Reform: The Story of Left Policy Transition in West Bengal." Journal of South Asian Development 10(2):199-299.

Dey, Partha. 2011. Sarkar Jokhon Luthera. Kolkata: Nagarik Mancha Publications.

Dey, Ishita, Ranabir Samaddar, and Suhit Sen. 2013. Beyond Kolkata: Rajarhat and the Dystopia of Urban Imagination. New Delhi: Routledge.

District Statistical Handbook. 1996-2004. "North 24-Parganas." Ministry of Statistics and Programme Implementation. GoWB.

Dutta, Nilotpal, ed. 2010. Rajarhate Jomi Dakatir Itihash. Calcutta: Save Rajarhat Land Committee Publication.

Feldman, Shelly and Charles Geisler. 2012. "Land Expropriation and Displacement in Bangladesh.” Journal of Peasant Studies 39(3-4):971-93.

Foucault, Michel. 1991. Discipline and Punish: The Birth of a Prison. London: Penguin.

Franda, Marcus. 1971. Radical Politics in West Bengal. Cambridge, MA: The MIT Press.

Gardner, Katy and Eva Gerharz. 2016. “Land, 'Development' and 'Security' in Bangladesh and India: An Introduction.” South Asia Multidisciplinary Academic Journal 13. Retrieved April 20, 2019 ( http://samaj.revues.org/4141).

Gardner, Katy, Zahir Ahmed, Fatima Bashir, and Masud Rana. (2012). "Elusive Partnerships: Gas Extraction and CSR in Bangladesh." Resources Policy 37(2):168-74.

Goldman, Michael. 2011. "Speculative Urbanism and the Making of the Next World City." International Journal of Urban and Regional Research 35(3):555-81.

Gooptu, Nandini. 2011. "Economic Liberalization, Urban Politics and the Poor." Pp. 35-48 in Understanding India's New Political Economy: A Great Transformation?, edited by S. Ruparelia, S. Reddy, J.Harriss, and S. Corbridge. Oxford: Routledge.

Government of West Bengal (GoWB). 1999. Report on the Rehabilitation and Resettlement Committee for Project Affected People of New Town Project. Retrieved July 17, 2019 (http:// www.wbhidcoltd.com/uploads/reports/report5.pdf).

Government of West Bengal (GoWB). 1998. Report on the Status of Environment in West Bengal. Calcutta: West Bengal Pollution Control Board.

Guerin, Isabelle, G. Venkatsubramian, and Sébastian Michiels. 2015. "Labour in Contemporary South India." Pp. 118-35 in Indian Capitalism in Development, edited by B. Harriss-White and J. Heyer. Oxon: Routledge.

Gupta, Akhil and Aradhan Sharma. 2006. "Globalization and Postcolonial States." Current Anthropology 47(2):277-307.

Hall, Derek. 2013. "Primitive Accumulation, Accumulation by Dispossession and the Global Land Grab." Third World Quarterly 34(9):1582-604.

Harvey, David. 2003. The New Imperialism. Oxford: Oxford University Press.

Harriss-White, Barbara and Judith Heyer, eds. 2015. Indian Capitalism in Development. Oxon: Routledge. 
HIDCO. 1995. New Town at Rajarhat: Task Force Project Report. GoWB.

HIDCO. 1999. Land Use and Development Control Plan. GoWB.

HIDCO. 2012. Land Use and Development Control Plan for New Town Planning Area. GoWB. Retrieved July 17, 2019 (http://www.wbhidcoltd.com/uploads/reports/report11.pdf).

Johnson, Craig and Arpana Chakravarty. 2013. "Re-thinking the Role of Compensation in Urban Land Acquisition: Empirical Evidence from South Asia." Land (2):278-303.

Karmakar, Joy. 2015. "Encountering the Reality of the Planning Process in Peri Urban Areas of Kolkata: Case Study of Rajarhat.” Archives of Applied Science Research 7(5):129-38.

Khan, Mushtaq Husain. 2004. "Power, Property Rights and the Issue of Land Reform: A General Case Illustrated with Reference to Bangladesh." Journal of Agrarian Change 4(1-2):73-106.

Le Mons Walker, Kathy. 2008. "Neoliberalism on the Ground in Rural India: Predatory Growth, Agrarian Crisis, Internal Colonization, and the Intensification of Class Struggle." Journal of Peasant Studies 35(4):557-620.

Levien, Michael. 2013. "Regimes of Dispossession: From Steel Towns to Special Economic Zones." Development and Change 44(2):381-407.

Levien, Michael. 2012. "The Land Question: Special Economic Zones and the Political Economy of Dispossession in India." Journal of Peasant Studies 39(3-4):933-69.

Mahadevia, Darshini, ed. 2008. Inside the Transforming Urban Asia: Processes, Policies and Public Actions. New Delhi: Concept.

Makki, Fouad. 2014. "Development by Dispossession: Terra Nullius and the Social-Ecology of New Enclosures in Ethiopia." Rural Sociology 79(1):79-103.

Marx, Karl. 1976 Capital: A Critique of Political Economy. vol. 1. Translated by B. Fowkes. London: Penguin.

Mukherjee, Angana. 2016. "Villages in the City: Trajectories of Urbanisation in Rajarhat-New Town, Kolkata." MPhil Thesis, School of Habitat Studies, Tata Institute of Social Sciences. Retrieved July 17, 2019 (http://dspace.tiss.edu/jspui/handle/1/7463).

Münster, Daniel and Ursula Münster. 2012. "Consuming the Forest in an Environment of Crisis: Nature Tourism, Forest Conservation and Neo-liberal Agriculture in South India." Development and Change 43(1):205-27.

Nielsen, Kenneth Bo. 2018. Land Dispossession and Everyday Politics in Rural Eastern India. New York: Anthem.

Nielsen, Kenneth Bo. 2015. "Law and Larai: The (De)Judicialisation of Subaltern Resistance in West Bengal." Journal of Contemporary Asia 45(4):618-39.

Nielsen, Kenneth Bo and Patrik Oskarsson, eds. 2017. Industrialising Rural India: Land, Policy and Resistance. Oxford: Routledge.

Padel, Felix and Samarendra Das. 2010. Out of This Earth: East India Adivasis and the Aluminium Cartel . New Delhi: Orient Blackswan.

Parasuraman, S. 1999. The Development Dilemma: Displacement in India. London: Macmillan Press Ltd.

Randeria, Shalini. 2003. "Cunning States and Unaccountable International Institutions: Legal Plurality, Social Movements and Rights of Local Communities to Common Property Resources." European Journal of Sociology 44(1):27-60. 
Robinson, Jennifer. 2002. "Global and World Cities: A View from off the Map." International Journal of Urban and Regional Research 26:531-54.

Roy, Ananya. 2011. "The Blockade of the World-Class City: Dialectical Images of Indian Urbanism." Pp. 259-78 in Worlding Cities: Asian Experiments and the Art of Being Global, edited by A. Roy and A. Ong. Malden, MA: Wiley-Blackwell.

Roy, Ananya. 2005. “Urban Informality: Toward an Epistemology of Planning." Journal of the American Planning Association 71:147-58.

Roy, Ananya. 2004. “The Gentleman's City: Urban Informality in the Calcutta of New Commonism." Pp. 147-70 in Urban Informality: Transnational Perspectives from the Middle East, Latin America, and South Asia, edited by A. Roy and N. AlSayyad. Lanham, MD: Lexington Books.

Roy, Ananya. 2002. City Requiem, Calcutta: Gender and the Politics of Poverty. Minneapolis, MN: University of Minnesota Press.

Roy, Dayabati. 2012. "Caste and Power: An Ethnography in West Bengal.” Modern Asian Studies 46 (4):947-74.

Roy, Rajat. 2016. "Nothing Succeeds like Success in West Bengal." Economic and Political Weekly 51 (22):24-26.

Ruud, Arild Engelsen. 1994. "Land and Power: The Marxist Conquest of Rural Bengal." Modern Asian Studies 28(2):357-80.

Sarkar, Tanika and Sumit Chowdhury. 2009. "The Meaning of Nandigram: Corporate Land Invasion, People's Power, and the Left in India.” Focaal: European Journal of Anthropology (54):73-88.

Samaddar, Ranabir. 2013. “Whatever has Happened to Caste in West Bengal?" Economic and Political Weekly 48(36):77-79.

Sassen, Saskia. 2006. Denationalization: Territory, Authority and Rights. Princeton, NJ: Princeton University Press.

Sen, Dwaipayan. 2014. "Representation, Education and Agrarian Reform: Jogendranath Mandal and the Nature of Scheduled Caste Politics, 1937-1943." Modern Asian Studies 48(1):77-119.

Sengupta, Santanu. 2008. A History of the Brutal Rajarhat Land Acquisition, Bengal's New IT Hub. The Sanhati Collective. Retrieved December 19, 2018 (http://sanhati.com/excerpted/945/).

Sinharay, Praskanva. 2012. “A New Politics of Caste." Economic and Political Weekly 47(34):26-7.

Tawa Lama-Rewal, Stépanie. 2009. "The Resilient Bhadralok: A Profile of the West Bengal MLAs." Pp. 361-92 in Rise of the Plebeians? The Changing Face of Indian Legislative Assemblies, edited by C. Jaffrelot and S. Kumar. New Delhi: Routledge.

Woods, Michael. 2011. Rural: Key Ideas in Geography. Oxon: Routledge.

\section{NOTES}

1. There is an emerging body of literature on this theme. See, for example, Levien (2013); Feldman and Geisler (2012); Adnan (2013); Cross (2014).

2. A mouza is an area comprising multiple settlements, taken as a revenue collection unit in a pargana (revenue district).

3. Eventually, 45 mouzas were notified for acquisition (HIDCO 2012). 
4. As per HIDCO (2012), the entire planning area today stands at 9390 hectares. 6839.31 hectares had been acquired by 2012 .

5. A katha (or kattha or cottah) is a unit of land measurement, approximately equal to 720 sq. feet or 66.89 sq. metres.

6. Nagarik Mancha (citizens' platform) is a Kolkata based non-political civil society organisation.

7. It is difficult to ascertain the caste affiliations of the primary victims of the urbanisation process, as neither existing government reports nor any other study documents that level of detail. But anecdotal evidence across the villages reflects a familiar pattern of low caste groups suffering the brunt of it (particularly the Namasudra caste, which is the most prominent across Rajarhat)

8. Between 1998 and 2001, the records show no change in the data, hence it is encapsulated in one row.

9. Interview, $20^{\text {th }}$ April 2017, Salt Lake, Kolkata.

10. Interview, $21^{\text {st }}$ April 2017, Kolkata.

11. There is also a strong body of historical and sociological literature on caste dynamics in colonial Bengal (Bandyopadhyay 1990; Chatterjee 1979; Sen 2014), and also in contemporary West Bengal (Roy 2012).

12. Literally meaning "respectable people" or "gentlemen," an elite class of regional intelligentsia unique to the Bengali-speaking area. The mainstay of Bengali communism, the bhadralok, had turned to Marxism as a political creed in the 1930s (Franda 1971; Chatterjee 1997). The bhadralok status was not ascribable but had to be achieved via cultural and political sophistication, where caste was supposedly not important. In reality, the bhadralok belonged overwhelmingly to the upper castes, whilst the lower castes, predominantly involved in low-paid manual jobs, were referred to as the chhotolok (low/non-respectable people). The term chhotolok can also be a term of abuse, often used by the bhadralok to denigrate one of their own caste (Roy 2012). The embedded politics of caste-hierarchy is thus not only entrenched in the uppercaste consciousness, but beneath the radar of aggregate electoral politics, continues as a key organising principle of social lives (Chandra et al. 2015).

13. The available public data from the district statistical handbooks is often not updated, as evident here (the total population and Muslim population data remains unchanged between 2001 and 2003). Subsequent handbooks until 2011 use the same 2003 data.

14. Interview, $9^{\text {th }}$ April 2017, Aatghora, Rajarhat.

15. Interview, $10^{\text {th }}$ April 2017, Tarulia, Rajarhat.

16. Interview, $20^{\text {th }}$ April 2017, Patharghata, Rajarhat.

17. Interviews, $20^{\text {th }}$ and $21^{\text {st }}$ April, Patharghata, Tarulia, and Mahishbathan, Rajarhat.

18. Interview, $20^{\text {th }}$ April 2017, Patharghata, Rajarhat.

19. It is also possible to add the term gorib-lok, which means the economically poor, to this terminology. The bhadralok can be a gorib-lok as well (although rarely), but is likely to be looked upon sympathetically owing to his social/cultural capital. The borolok is not poor, but is looked upon suspiciously for having progressed in class terms despite coming from a lower social stratum. And it is almost natural for the chhotolok to also remain a gorib-lok owing to his lowcaste. However, out of all the terms, gorib-lok is an expression of class-relations alone, while the rest are indicative of either caste-status (chhotolok) or both (bhadralok and borolok). Hence the focus is on the tripartite terminology.

20. Interview, $30^{\text {th }}$ April 2017, Rajarhat.

21. Interview, $1^{\text {st }}$ May 2017, Aatghora, Rajarhat.

22. Interview, $1^{\text {st }}$ May 2017, Mahishbathan, Rajarhat.

23. Interview, 22nd April 2017, Patharghata, Rajarhat. 


\section{ABSTRACTS}

This paper explores the political churnings around an almost twenty-year-old process of land acquisition and development in Rajarhat, an erstwhile rural settlement in the Indian state of West Bengal. The narrative takes shape against the backdrop of a neo-liberal state in the global South acting as a corporate facilitator, the concomitant dispossession, and particularly the transformation of the villages and rural livelihoods. The paper tries to trace the nature of this transformation by mapping the socio-economic changes on the one hand, and the reinvention of traditional caste-based social hierarchies brought about by such changes on the other, and highlights the formation of "syndicates" (low-level cartels) in the area as a unique manifestation of the latter. Such developments, the paper argues, symbolize a qualitative shift in rural social relations, brought about by rapid urbanization in neoliberal India.

INDEX

Keywords: Rajarhat, West Bengal, CPIM, caste, displacement, syndicate

\section{AUTHOR}

\section{RITANJAN DAS}

Business and Law Department, University of Portsmouth, Portsmouth, United Kingdom 